\title{
Chapter 20 \\ The Relationship between Current Account Deficits and Unemployment in Turkey
}

\author{
Mustafa Ozer \\ Anadolu University, Turkey \\ A. Erinç Yeldan \\ Bilkent University, Turkey
}

\begin{abstract}
In this chapter, we test the nature of the variety of empirical relationships between current account deficits and unemployment in Turkey over 2000Q1-2012Q1. Our working hypothesis in this paper is that the meager job creation in Turkey over 2000s is the direct symptom of a speculative-led growth environment (Grabel, 1995) together with an excessively open and unregulated capital account in the age of relatively cheap and abundant global finance. Based on the vector error correction model (VECM), we found that there is a unidirectional causality running from current account deficits to unemployment. Both Impulse Response and Variance Decomposition analyses are quite consistent with results of VECM. We interpret these findings as evidence of the structural characteristics of unemployment, reflected in output elasticities, being embedded under the deepening external fragility of the Turkish economy over the 2000s.
\end{abstract}

\section{INTRODUCTION}

A major enigma of the Turkish macroeconomic path over the 2000s was the relatively high and persistent rate of open unemployment. This observation came at odds against rapid growth and a significant surge in exports over the decade. The rate of open unemployment which stood at $6.5 \%$ in 2000 has jumped to $10.3 \%$ in 2002 in the after- math of the February, 2001 financial crisis. Since then, the Turkish Gross Domestic Product (GDP) has increased by a cumulative $40 \%$ in real terms. Nonetheless, employment generation capacity of this rapid growth had been rather dismal, and the open unemployment rate could not be brought down below $9 \%$ by the end-of 2007 , just before the eruption of the current global economic crisis. Despite rapid expansion of production in many

DOI: 10.4018/978-1-4666-9548-1.ch020 
sectors, civilian employment increased sluggishly at best, and labor participation remained below its levels as observed during the 1990s.

The medium term economic program, 20132015, chartered by the Turkish State Planning Organization (SPO) as well documents that unemployment is expected to remain at the plateau of $10 \%$ over the programming horizon. A further caution is that Turkish labor market is suffering from informalization and marginalization, with low labor participation rates, lack of health and social safety nets, and increased fragmentation. These assessments are also shared by many other national and international agencies and researchers of the Turkish economy.

According to some interpretations, the meager job creation of the economy is due to the excessive regulatory framework and the imposed tax burden. Turkey indeed has one of the highest tax burdens in its labor markets in comparison to the OECD averages. Tunalı (2003), for instance, reports that the social security contributions of the employers reach to $22 \%$, and together with other taxes on labor employment, create an additional cost burden for employers reaching as much as $35 \%$ over net wages. Tunalı further argues that employment protection laws may have increased the insecurity faced by the workers as employees try to avoid severance payments by shifting their labor demand to workers mostly from the informal market. This undoubtedly has adverse consequences for tax revenues and also on the formal industrial relations.

Ercan and Tansel (2007), on the other hand, report that it is the Labor Act introduced in 2003 which was the main source of the problem. The Law is criticized (mostly by the employers' wing) on the grounds that the job security clauses that had been introduced in 2003 led the employers to be more reluctant in expanding formal employment. Ercan and Tansel also summarize the workers' unions' opposition to this argument stating that it is the first time with the new act, "flexi-time" and "flexible work" de-regulations entered the
Turkish labor scene. Yet despite conducive policies towards the desired "flexibilities", still not enough jobs have been created. In fact, existing studies claim in this regard that labor market regulations and other "distortions" in the formal economy may actually not binding for the larger segment of the labor market (Agénor et al, 2007; Onaran, 2009). Onaran (2013), for instance, argue that wages actually exhibit a high degree of flexibility as the power of trade unions has eroded significantly in the past two decades.

An alternative hypothesis is that the jobless growth problem ought to be regarded as a direct symptom of the current macroeconomic framework together with an excessively open capital account and widespread financial speculation. According to this line of thought, due to virtually an unregulated capital account and the relatively high real rates of interest prevalent in the Turkish financial markets, Turkey is observed to receive massive inflows of short term finance capital. As a result, the domestic currency, $T L$ (Turkish Lira), appreciates and Turkey suffers from a widening current account deficit. Appreciated currency brings forth a surge in imports together with a contraction of labor intensive, traditional export industries such as textiles, clothing, and food processing. This leads to contraction of formal jobs and increased informalization of economic activities (see Yeldan, 2006, 2011; Onaran, 2008).

In fact, a further key distinguishing feature of the Turkish economy over the 2000s was the eruption of the current account deficits in almost a structurally permanent manner. Traditionally Turkey used to display a fair balance in its current account. However, starting 2003 annualized current account deficit, as a ratio to the gross domestic product, increased to the $3-4 \%$ band, and then jumped above $6 \%$ after 2006 to reach a record high $9.7 \%$ in 2011.

Our working hypothesis in this chapter is that the meager job creation in Turkey over the 2000s is the direct symptom of a speculative-led growth environment (a la Grabel, 1995) together with an 
excessively open and unregulated capital account in the age of relatively cheap and abundant global finance. Accordingly, with the available bonanza of relatively cheap external credit, Turkey could have financed its imports via rapid accumulation of external debt. Substitution of imports for domestic production led to lower value added production at home. Thus, the problem of poor job performance and the fragility embedded in the increase of the current account deficits were, in fact, manifestations of the same adjustment mechanism under a speculative finance-led growth path.

We study this hypothesis utilizing time series econometrics based on Johansen co-integration and Granger causality techniques. Focusing on quarterly data over 2000 to 2012, we investigate the co-integration and causality between unemployment and external balance for the Turkish economy. Our findings reveal that current account deficits explain a substantial fraction of the variation in unemployment and suggest the presence of strong unidirectional causality.

The structure of this chapter is as follows: The next section provides an overview of the macroeconomics of external deficits and employment performance of the Turkish economy over the 2000s. Section 3 introduces our econometric methodology. Section 4 implements aseries of econometric tests. Section 5 concludes and suggests policy implications for future research.

\section{PATTERNS OF EXTERNAL DEFICITS AND UNEMPLOYMENT IN TURKEY OVER THE 2000S}

As a newly emerging market economy, Turkey had been subject to the patterns of the global business cycle over the 2000s. During the 1990s, the economy suffered from a high inflationary environment with unsustainable fiscal deficits. The unfavorable macroeconomic setting culminated into two severe financial crises in 1994 and 2001. Both of these were driven by speculative attacks of foreign finance capital that were led by the unsustainable rates of return under conditions of deep fiscal and external fragility.

In what follows, the post-2001 crisis adjustments came at a very unique conjuncture of the global economy. First of all, growth, while rapid, showed quite peculiar characteristics. It was mainly driven by a massive inflow of foreign finance capital which, in turn, was lured by significantly high rates of interest offered domestically; hence, it was speculative-led in nature (Grabel, 1995). The main mechanism has been that the high rates of interest prevailing in the Turkish asset markets attracted short term finance capital, and in return, the relative abundance of foreign exchange led to overvaluation of the $T L$. Cheapened foreign exchange costs led to an import boom both in consumption and investment goods. The overvaluation of the $T L$, together with the greedy expectations of the arbitrageurs in an era of rampant financial glut in the global finance markets, led to a severe rise in its foreign deficit, and hence, in external indebtedness.

A further characteristic of the post-2001 era was Turkey's poor job creation pattern. Rapid rates of growth were accompanied by high rates of unemployment and low participation rates. The rate of total unemployment rose to above $10 \%$ after the 2001 crisis, and despite rapid growth, has not come down to its pre-crisis levels. In fact, the most relevant observation from this history is that during the 2000s, despite rapid growth and a significant surge in exports, Turkish economy could not generate jobs at the desired rate.

To make this assessment clearer, we report on the elasticities of employment with respect to $G D P$; that is percentage gain in employment due to percentage changes in GDP growth (see Table 1). Data reveal the overall decline of the elasticities of employment by sectors in comparison to the 1990s. Average elasticity of employment for the whole domestic economy fell from 0.39 (19892000) to 0.14 (2002-2008). There had been labor shedding in agriculture, while the non-agricultural 
Table 1. Output Elasticities of employment by sectors (Annual averages)

\begin{tabular}{|l|c|c|c|}
\hline & $\mathbf{1 9 8 9 - 2 0 0 8}$ & $\mathbf{1 9 8 9 - 2 0 0 0}$ & $\mathbf{2 0 0 2 - 2 0 0 8}$ \\
\hline Total & 0.25 & 0.39 & 0.14 \\
\hline Agriculture & -1.19 & -0.42 & -1.66 \\
\hline Non-Agriculture Sectors & 0.54 & 0.68 & 0.48 \\
\hline Industry & 0.43 & 0.49 & 0.39 \\
\hline Services & 0.55 & 0.76 & 0.47 \\
\hline Source: Authors' calculations based on Turkstat and SPO data \\
\hline
\end{tabular}

sectors had significantly lower employment elasticities over the 2002-2008 period. All of these phenomena had been succinctly phrased as jobless growth for Turkey (see, e.g. Yeldan, 2012; Telli et al, 2006; Onaran, 2009; Taymaz et al, 2009).

The close relationship between meager job creation and the foreign deficits are portrayed succinctly in Figure 1. Here, in order to isolate for the effect of non-energy imports, we document the size of non-oil trade deficit. This is portrayed in reference to the right hand-axis. Due to the presence of high seasonality and the structurally driven nature of labor shedding in agriculture, the rural economy is also taken as exogenous to the Figure. Thereby, we follow the close relationship of the non-oil trade deficit together with the nonagricultural unemployment in Figure 1.

The portrayal of the rising non-agricultural unemployment along with an expanding (non-oil) trade deficit is no surprise to students of development economics. As Turkey consumed more and more of value added produced abroad, and found it profitable to do so with an appreciated currency financed by speculative financial inflows, external

Figure 1. Non-oil trade deficit and total unemployment in non-agricultural Sectors (Adapted from Turkstat Household Labor Force Statistics, and CBRT, Balance of Payments Statistics)

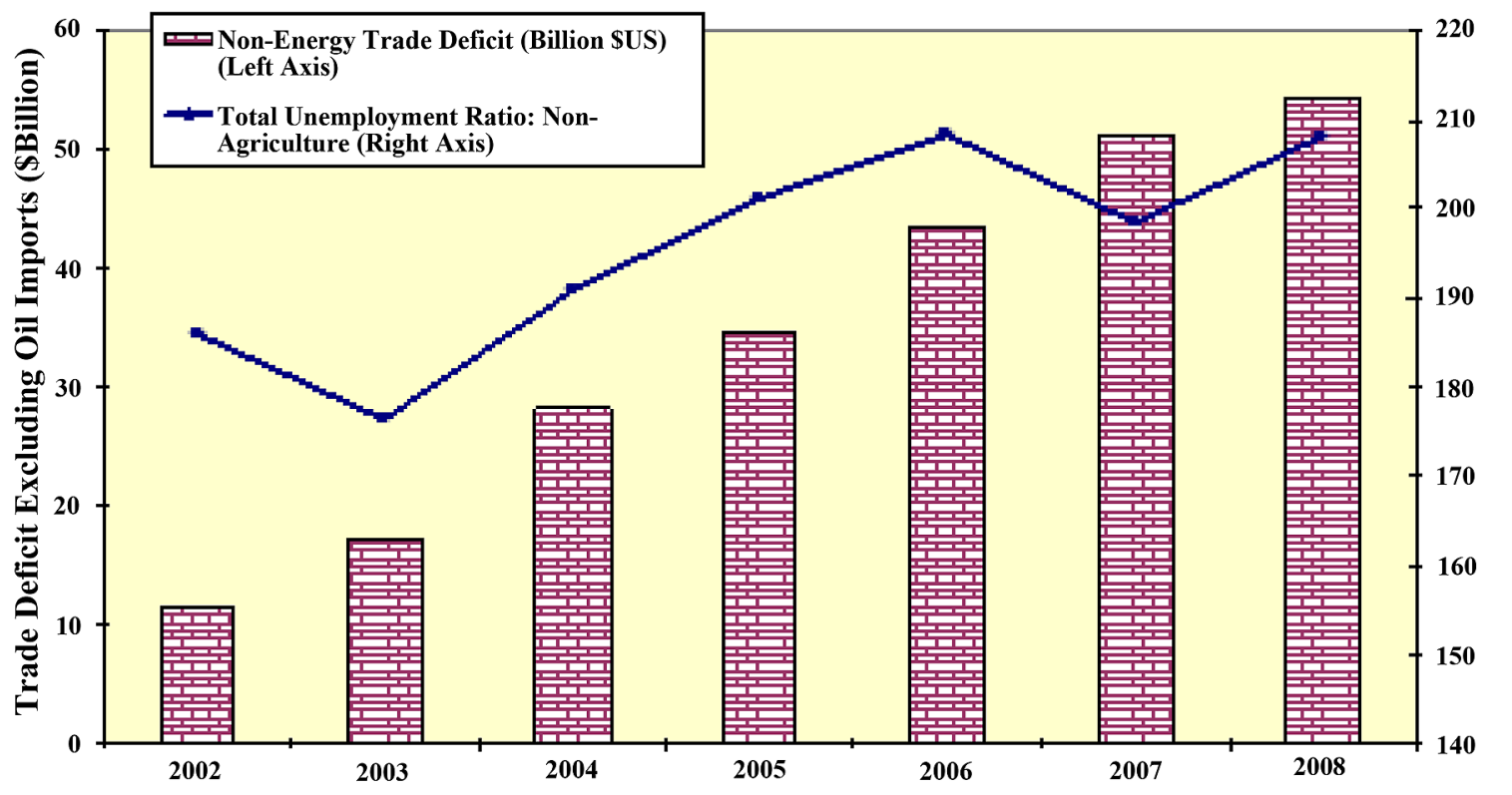


deficit widened and foreign debt accumulated. The costs of this speculative-led growth, however, were realized as loss in jobs, deepening informalization, and decline of real wage income.

Figure 2 depicts the evolution of the real unit labor wage costs. Weighted by the productivity indexes, the fall in real unit labor costs indicates that the loss in export competitiveness due to currency appreciation could have been overcome only by depressing the real wage costs against productivity gains. In this manner, firms have tried to maintain their competitive edge in the global commodity markets.

Various channels can be cited to be at work for the potential negative effects of external imbalances on employment. First is the macroeconomic demand channel proper. With the fall in net exports, national economy is expected to suffer from deflation in aggregate demand at least in the short run. This Keynesian channel was also underlined in the late history of the Latin American economies by (Frenkel, 2006) who report that domestic production and employment had been substituted for external activity over the externally fragile environment of the 1990s. This effect could further be reinforced with the pressure of intermediate imports to lower the ratio of value added in gross output.

With the rise of the share of imported intermediates in gross production, domestic value added falls, with adverse consequences on employment. This latter effect is revealed by (Nucci et al, 2010) in the context of currency appreciations. In their panel econometrics work on Italian manufacturing firms, Nucci and Pizzolo report that the response of jobs and hours worked to currency swings depends primarily on the firms' exposure to foreign sales and their reliance on imported inputs; with the degree of substitutability between imported and other inputs playing a key role in the metrics of employment sensitivities.

A second channel can be envisaged to operate through the factor substitution effect. Relative cheapening of (imported) capital directs producers to substitute out labor, generating pressures for a more capital-intensive input mix. A recent study on the total factor productivity and revealed factor ratios of the post-1990 Turkish industry

Figure 2. Real Unit Labor Costs: Turkey Total Economy (ratio of compensation per employee to nominal GDP per person employed [ECU/EUR])

(Adapted from European Commission Economic and Financial Affairs, AMECO data base)

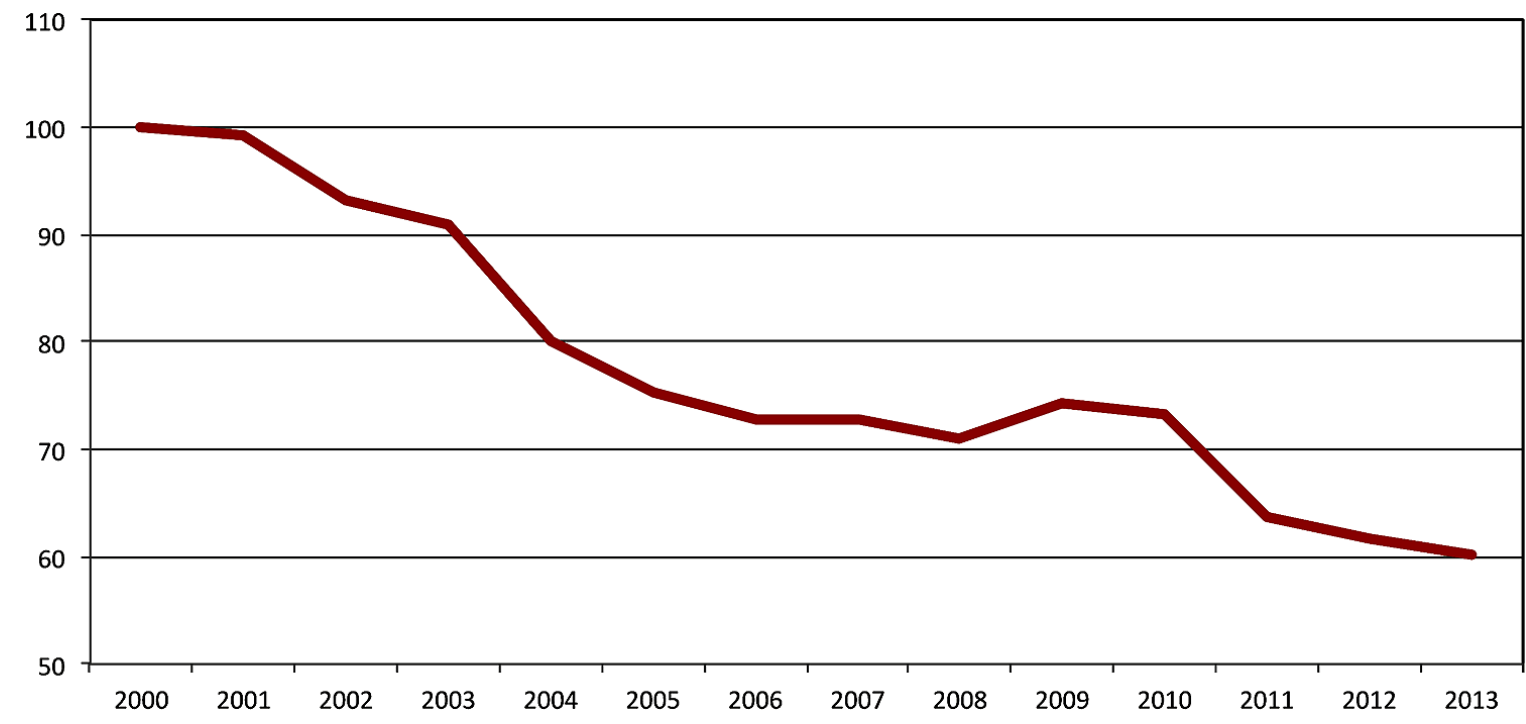


Figure 3. Capital labor ratio in Turkish manufacturing (In fixed 1998 prices, TL) Source: Yeldan and Kolsuz (2014).

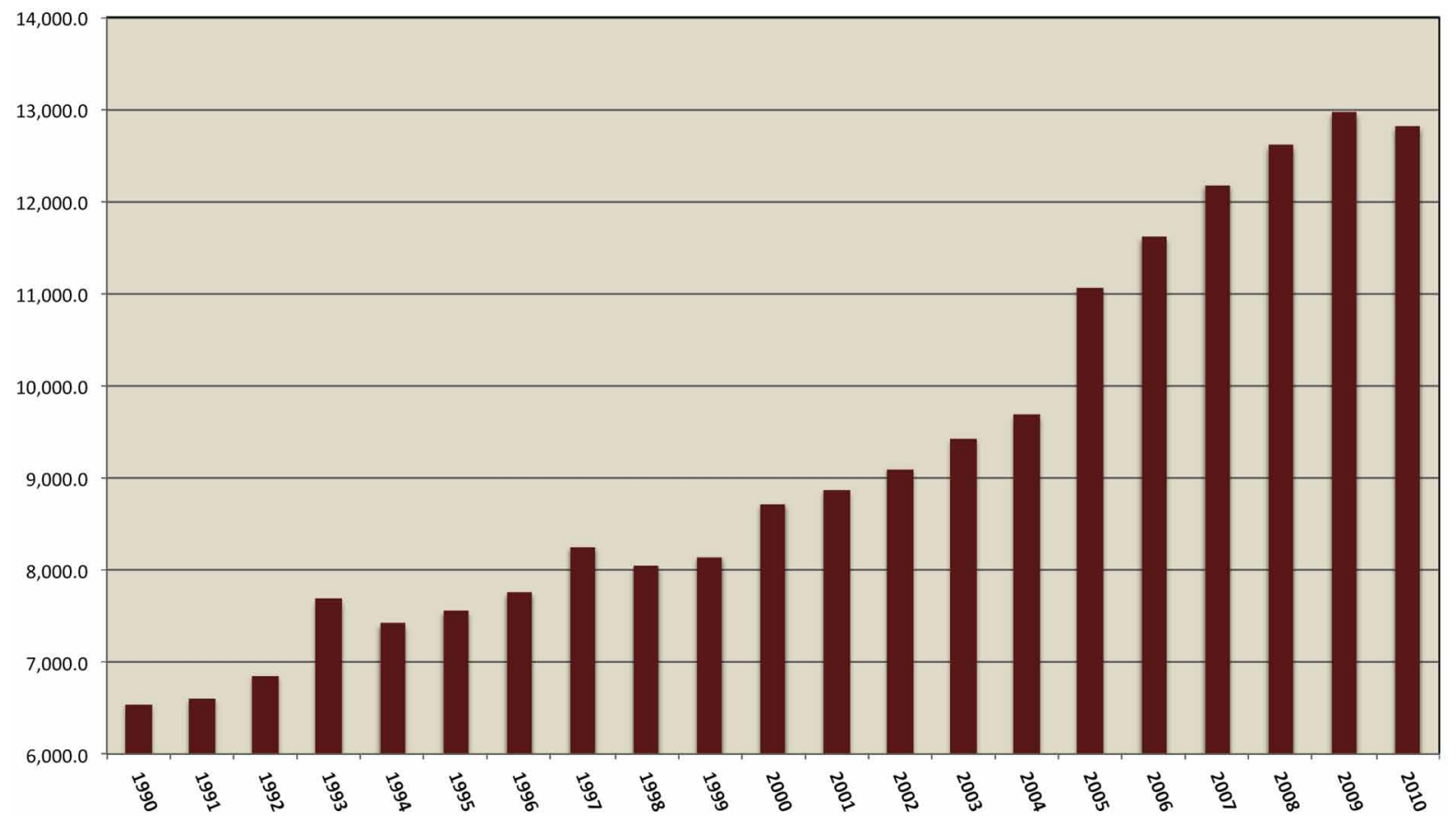

as conducted by (Yeldan \& Kolsuz, 2014) corroborate this prognostication. In their study of the estimates of (physical) capital utilization in Turkish manufacturing over the 1990-2010 period, they report that capital per labor had increased by more than two-folds in real terms (See Figure 3 ). The biggest jump is observed to come after 2004, during when the current account balance worsened secularly.

Related to this one can conjecture a dynamic efficiency channel, wherein the long term accumulation and productivity rates are distorted with adverse effects on the speed of generation of new jobs. The analytics of this route were formulated in a seminal paper by (Ros et al., 1998) and were studied empirically in (Frenkel et al., 2006) in the context of the Latin American economies. Determinants of dynamic efficiency and long run growth extend, surely, beyond the balance of the external economy. Long run growth is to be directly shaped by the position of the domestic economy in relation to the ladder of the global value chains, and the dynamic shifts in the heterogeneous composition of sectoral production play a key role in the resolution of the employment patterns.

Aksoy (2013) and Meschi et al (2011) report the positive feedback mechanisms of trade generation and skill upgrading due to export penetration and capital imports with significant spillovers on skilled employment in Turkish manufacturing. In contrast, Taymaz et al. (2008), Taymaz et al. (2005), and Taymaz et al. (2009) caution on the strains of the ongoing substitution of skilled labor against the traditional lines of employment and document the loss in jobs particularly in food processing, textiles and mining and quarrying. Over the course of the great recession, that is from October 2008 onwards, the number of people employed by the Turkish manufacturing industry remains at roughly 150 thousands (which represents a $3.5 \%$ increase in employment). The fact that since October 2008, the manufacturing 
industry has expanded by $30 \%$ in real terms while the labor force could have grown by only $3.5 \%$ indicates the capital-intensive characteristics of the industrialization path of the Turkish economy.

The mode of operation of these channels was not unidirectional, and necessitated indirect links via the currency and product markets. Here the key variables are the real exchange rate and the real rate of interest. A distinguishing feature of the Turkish economy over the 2000 s was the relatively high real rates of interest. Higher interest rates together with a restrictive monetary stance were conducive in attracting capital inflows and controlling for inflationary pressures. Yet, the negative effects of high interest rates on employment are wellknown (Nickell et al., 1999; UNCTAD, 2006). In the Turkish historical context, high interest rates in the post-2001 era signified strong inflows of speculative capital.

It has to be recalled that the 2000's was the era of great moderation together with flexible (floating) exchange rate regimes, independent, inflation targeting central banks with the objective of price stability and freely mobile capital flows. In return to all these, Turkey witnessed severe appreciation of the $T L$ from 2003 to 2008 . The $T L$ had appreciated by as much as $60 \%$ in real terms against the US dollar. The onset of great recession in October of 2008 had caused depreciation of the $T L$ somewhat, yet well short of maintaining its real level of January, 1982 (Figure 4).

The structural overvaluation of the $T L$, not surprisingly, manifests itself in ever-expanding deficits on the commodity trade and current account balances. In what follows, starting in 2003 Turkey has witnessed expanding current account deficits, with the figure in 2011 reaching a recordbreaking magnitude of US\$78.1 billion, or $9.7 \%$ as a ratio to the aggregate GDP. In appreciation of this figure, it has to be noted that Turkey traditionally has not been prone to current account deficits. Over the last two decades (1980s and 1990s) the average of the current account balance hovered around plus and minus $1.5-2.0 \%$, with deficits exceeding 3\% typically signaling significant currency adjustments.

Figure 4. Real Exchange rate index (TL/USD) (PPP in consumer prices) (Adapted from TR Central Bank and TURKSTAT)

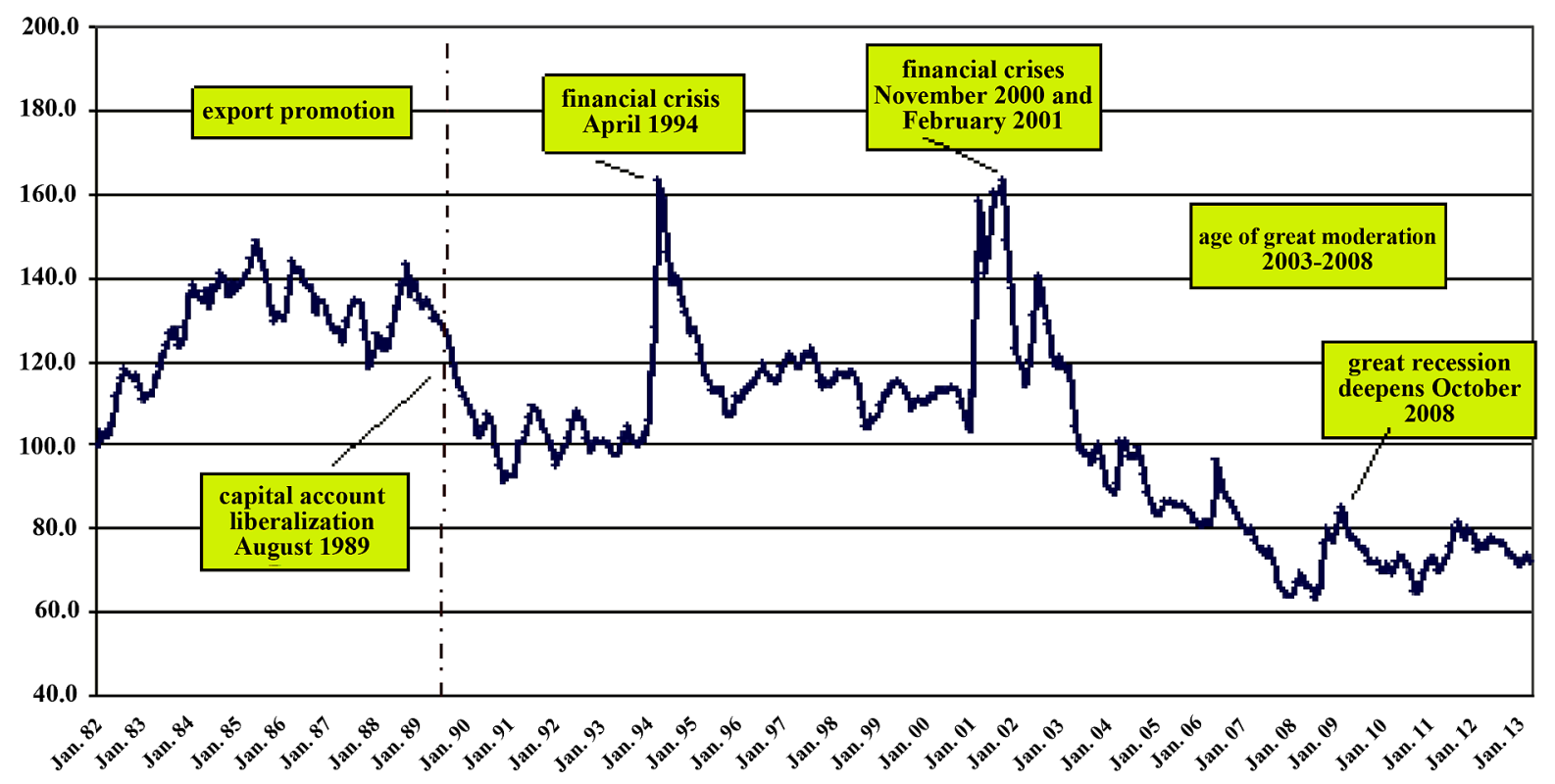


It ought to be noted as well that, for the determination of employment effects not only the level, but also the volatility of the exchange rate matters. The potential negative effects of exchange rate volatility are well-known in the literature (see, e.g. UNCTAD, 2006; Belke et al., 2004; Andersen et al., 1988) and are succinctly documented in the Turkish context in (Demir, 2010, 2013). In what follows, Belke et al. (2004) further studied the adverse effects of the revenue uncertainties on employment as generated by exchange rate volatilities and accompanied current account balances in the context of a formal model of risk-neutral firms facing sunk hiring and firing costs.

In fact, the volatility and the appreciation of currency together, would necessarily result in adverse balance sheet effects via the expectations channel. This is mostly due to the threat of expected depreciation in the face of a widening current account deficit. Frenkel et al. (2006) report of a statistically significant negative effect of currency appreciation on employment growth in their study of the 17 Latin American economies, while Ribero et al (2004) documents the negative employment effects of real exchange rate appreciation in Brazil. Similarly, (Galindo, et al., 2007) show that, in response to worsening external balances, the warranted currency depreciations are likely to generate negative employment effects in regimes of high liability dollarization.

In what follows, in our econometric investigation our main focus will be on the employment effects of current account imbalances, but not on the sources of these imbalances themselves. This, surely, should not be regarded to mean that we ignore the importance of the sources of such imbalances. We need to note that many factors such as risk premia, nature and size of capital flows, expectations, level of international reserves, and the level of financial deepening have much to contribute in the determination of external balances, a thorough analysis of which are clearly beyond the scope of this chapter. ${ }^{1}$
All these observations leave us with the working hypothesis that the persistent unemployment problem in Turkey over the 2000s has strong structural features rooted in the externally fragile macroeconomic environment, as is seen in Table 1. It is this issue that we now turn in more formal terms.

\section{METHODOLOGY}

This section highlights the methodologies that this chapter uses to explore the dynamic linkages between current account deficits (CAD) and unemployment in Turkey over the 2000Q1-2012Q1 period. We prefer to use Granger causality test method to examine possible causal relationships between CAD and unemployment in Turkey in light of Monte Carlo evidences as provided by (Guilkey et al., 1982).

To carry out the Granger causality test, we first investigate the order of integration of the series using different unit root tests and then test existence of cointegration between series by employing Johansen cointegration test to confirm that the Granger causality tests will not produce any spurious results (AuYong et al., 2004). Secondly, we try to identify the short-run and long-run causality between these variables using VECM framework. Finally, based on the impulse responses and variance decomposition, we try to analyze the dynamic relations between the two series.

\section{Unit Root Test}

Since the Granger causality test requires determination of the order of integration series, we first examined stochastic properties of two series by applying Augmented Dickey-Fuller (ADF) test, Phillips-Perron (PP) test, Kwiatkowski-PhillipsSchmidt-Shin (KPSS) test, andZivot and Andrews (ZA) test. 
When interpreting the results of the ADF test, we must be aware of two crucial facts. Firstly, this test is very sensitive to incorrect establishment of the lag structure. Secondly, it is often known as significant under-rejection (Gurgul et al., 2011). It is now well known that ADF test has a low power in rejecting the null of a unit root (Liang et al, 2006). Therefore, in order to confirm the outcomes of the ADF test, PP and KPSS tests are also conducted.

ADF, PP and KPSS types' traditional unit roots tests are not reliable when there is a structural break in the series, since these tests tend to be biased in favor of the null of a unit root if there is a structural break in the series. To solve this problem, we perform Zivot-Andrews a single structural break unit root test that treats the occurrence of the break date as unknown. The ZA test allows for endogenous one-time break in intercept and/or trend.

\section{Cointegration Test}

According to Engle and Granger (1987), if nonstationary time series have the same order of integration, for example order one, and if these time series' linear combination exist and stationary, which is integrated of order zero, then these time series are called cointegrated time series. As stated in Love et al. (2005), once we found that the variables are non-stationary at their level and are stationary at their in first differences, we have to check whether they are cointegrated by employing Johansen framework details of the method can be found in Johansen (1988) and Johansen and Juselius (1990).

Two likelihood ratio (LR) tests are used for detecting the presence of co-integrating vectors in Johansen Procedure. The first is the trace test, which tests the null of at most $r$ co-integrating vectors against the alternative that it is less than r. The second is the maximum eigenvalue test, which tests the null of $r$ co-integrating vectors against the alternative of $r+1$. Both test statistics are distributed asymptotically as $\chi^{2}$ with $\mathrm{p}-\mathrm{r}$ degrees of freedom.

\section{Causality Test}

The Granger (1969) causality test, which is designed to detect direction of the possible causal relationship between two time series by examining a correlation between the current value of one variable and past values of another variable, often conducted in the context of a vector autoregression (VAR). According to (Granger, 1969), X Granger causes $\mathrm{Y}$, if current value of $\mathrm{Y}$ can be predicted better by taking into account of past values of $\mathrm{X}$ than by not doing so, provided that all other past information in the information set is used.

According to Granger representation theorem, if both current account deficit and unemployment are first difference stationary, and they are cointegrated, then there must be at least unidirectional Granger causality between these two variables. Additionally, in the case of cointegration, Engle and Granger (1987) warned that if the Granger causality test is conducted at first difference through vector auto regression (VAR) then the results of Granger causality tests will be misleading. Moreover, inclusion of error-correction term to the augmented version of Granger causality test will allow us to capture the long-run causal relationship. Therefore, we include the error-correction term in the augmented version of Granger causality test and following a bivariate $p$ th order vector error-correction model (VECM) is formed:

$$
\begin{aligned}
& \Delta \text { unemp }_{t}=\alpha_{1}+\sum_{i=1}^{p} \beta_{i} \Delta c a d_{t-i} \\
& +\sum_{j=1}^{q} \delta_{j} \Delta \text { unemp }_{t-j}+\varphi_{1} e c t_{1 t-1}+\varepsilon_{1 t}
\end{aligned}
$$




$$
\begin{aligned}
& \Delta \text { cad }_{t}=\alpha_{2}+\sum_{j=1}^{q} \phi_{j} \Delta \text { unemp } p_{t-j}+ \\
& \sum_{i=1}^{p} \gamma_{i} \Delta c a d_{t-i}+\varphi_{2} e c t_{2 t-1} \varepsilon_{2 t}
\end{aligned}
$$

where $\Delta$ is difference operator, $\mathrm{p}$ and $\mathrm{q}$ are the optimal lag lengths. ect $t_{t-1}$ denotes the lagged residual term obtained from the long-run relationship, $\varepsilon_{1 t}$ and $\varepsilon_{2 t}$ are normally distributed with zero mean and finite covariance matrix error terms. The coefficients, $\varphi_{1}$ and $\varphi_{2}$ of ect $_{\mathrm{t}-1}$, measure the error correction mechanism that derives the variables back to their long-run equilibrium relationship.

Using Equations (1) and (2), we can have the following different cases of causal relations (shortrun Granger causality) based on the Wald $\chi^{2}$-test; (i) current account deficits Granger-cause unemployment only when lagged values of $\Delta c a d$ in Eq. (1) may be statistically different from zero while values of $\Delta$ unemp are not in Eq. (2). The joint significance of the coefficients of lagged values of CAD variable indicates that the unemployment responds to short-run shocks to the stochastic environment. (ii) Unemployment Granger-cause current account deficits only when lagged values of $\Delta$ unemp in Equation (2) may be statistically different from zero while values of $\Delta c a d$ are not different from zero in Equation (1); (iii) bidirectional causality occurs when both the lagged values of $\Delta c a d$ and $\Delta$ unemp in Equations (1) and (2) are significantly different from zero and (iv) there is no causal relation between current account deficits and unemployment when both the lagged values of $\Delta c a d$ and $\Delta$ unemp in Equations (1) and (2) are significantly not different from zero. In this case, we can conclude that the variables are independently moving on their paths without influencing each other. We can detect presence of long-run causality by testing the statistical significance of coefficient of the error correction term $\left(e c t_{t-1}\right)$ with a negative sign.

\section{Impulse Response and Variance Decomposition Analyses}

Even though the VECM Granger causality approach allows determining the direction of Granger causality, it does not tell the sign of the causality. To determine the sign of the causality, a number of prior studies use the sum of the coefficients but, as argued in (Le et al., 2013), this approach may produce misleading results as there are all of the dynamic effects between Equations (1) and (2) that have to be considered. To capture the sign of the Granger causality, one has to look at the sign of the impulse responses (IRFs) for all periods. If the response function is positive for all periods, fading away to zero, this should be taken as an indication of positive causality. But on the other hand, it is positive, then negative, and then dampens down; it may be interpreted as a sign of absence of a clear-cut sign of causality. In this case, it could be said that the sign of causality depends on the time horizon.

As pointed out in Akinlo (2009) and also mentioned in Shahbaz (2012), by employing the VECM Granger causality test, one can only be able to test the causality among variables within the sample period. This result usually is considered as limitation of such test and it weakens the reliability of VECM Granger causality test results. Therefore, to capture the out of sample causality, the use of variance decomposition analysis is recommended. By portioning the variance of the forecast error of a certain variable, say unemployment, into proportions attributable to shocks in each variable, such as current account deficits, in the system including its own, VDCs might indicate Granger causality beyond the sample period. 
Data

In this study, we used quarterly data for Turkey from 2001Q1 to 2012Q2, as tabulated by the Central Bank of the Republic of Turkey and the Turkish Statistical Institute, Turkstat. Figure 5 displays the time series plots of all variables used in the study. Since unemployment and current account deficits exhibit clear seasonality, we used Tramo/Seats method to remove the seasonal component in both unemployment and current account series. Additionally, time series plots of all variables show a structural break following the 2008/09 crisis.

\section{ANALYSIS OF EMPIRICAL RESULTS}

Table 2 reports the unit root tests of ADF, $\mathrm{PP}$ and KPSS. ADF, PP and KPSS test results show that all variables are non-stationary at level and stationary at their first differences, that is, they are I(1).

The results of the three alternative specifications of the ZA test are presented in Table 3.

Clearly for all models (A, B, and C), the ZA tests fail to reject the null hypothesis of unit root with one structural break in levels, at all the conventional significance levels. Therefore, the ZA tests find no additional evidence against the ADF, PP, and KPSS unit root tests. For this reason, we

Figure 5. Unemployment, current account deficits, and seasonally adjusted unemployment and current account deficits series, Turkey
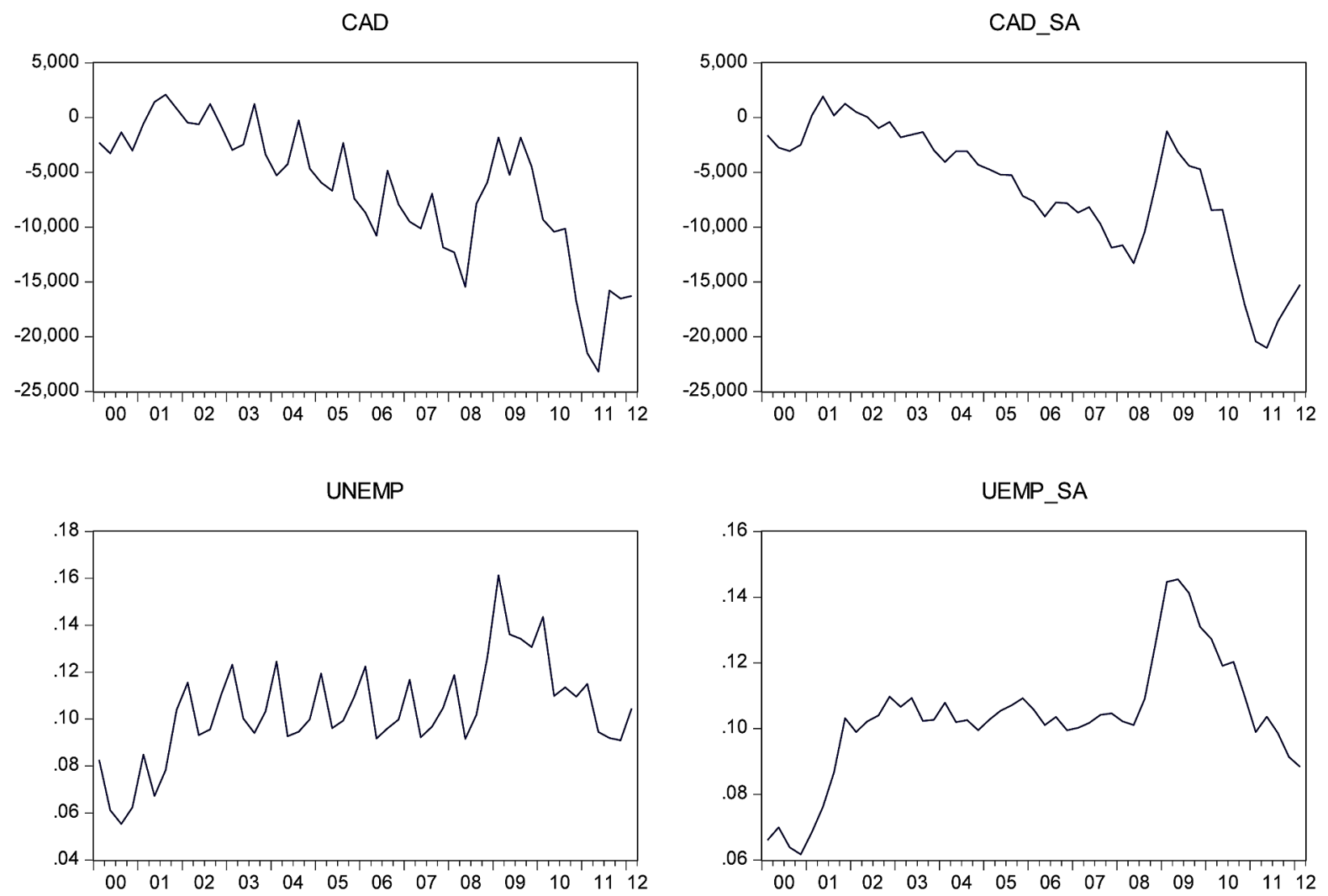
Table 2. Results of the unit root tests

\begin{tabular}{|c|c|c|c|c|c|c|c|}
\hline & Lag length & ADF & Bandwith & $\mathrm{PP}$ & Bandwith & KPSS & Conclusion \\
\hline CAD_SA & 1 & -1.49 & 2 & -1.15 & 5 & $0.71 * *$ & $\mathrm{I}(1)$ \\
\hline$\triangle C A D-S A$ & 0 & $-4.53 *$ & 0 & $-4.52 *$ & 2 & 0.06 & $\mathrm{I}(0)$ \\
\hline UNEMP_SA & 1 & -2.28 & 2 & -2.15 & 5 & $0.45^{* * * *}$ & $\mathrm{I}(1)$ \\
\hline$\triangle U N E M P$ SA & 0 & $-4.55^{*}$ & 1 & $-4.55^{*}$ & 3 & 0.26 & $\mathrm{I}(0)$ \\
\hline
\end{tabular}

Notes: For all tests, a constant is included. For the ADF test, optimal lag lengths are determined by using SIC with a maximum lag of 10. For both PP and KPSS tests the spectral estimation method is the Bartlett kernel, while bandwidth is the Newey-West.

*Denotes significance at the $1 \%$ level.

**Denotes significance at the $5 \%$ level.

$* * *$ Denotes significance at the $10 \%$ level.

Table 3. Results of ZA unit root tests

\begin{tabular}{|l|c|c|l|l|l|l|l|l|l|}
\hline & \multicolumn{3}{|c|}{ Model A } & \multicolumn{3}{c|}{ Model B } & \multicolumn{3}{c|}{ Model C } \\
\hline Variable & t-stat. & $\mathrm{k}$ & $\begin{array}{l}\text { Break- } \\
\text { date }\end{array}$ & t-stat. & $\mathrm{k}$ & $\begin{array}{l}\text { Break- } \\
\text { date }\end{array}$ & $\mathrm{t}$-stat. & $\mathrm{k}$ & $\begin{array}{l}\text { Break- } \\
\text { date }\end{array}$ \\
\hline CAD_SA & -4.57 & 2 & $\mathbf{2 0 0 8 Q 3}$ & -4.07 & 2 & $\mathbf{2 0 0 9 Q 2}$ & -5.93 & 2 & $\mathbf{2 0 0 8 Q 4}$ \\
\hline UNEMP_SA & -2.61 & 1 & $\mathbf{2 0 1 0 Q 2}$ & -2.92 & 1 & $\mathbf{2 0 0 9 Q 4}$ & -4.03 & 1 & $\mathbf{2 0 0 8 Q 4}$ \\
\hline $1 \%$ critical values & -5.34 & & & -4.80 & & & -5.57 & & \\
\hline $5 \%$ critical values & -4.93 & & & -4.42 & & & -5.08 & \\
\hline $10 \%$ critical values & -4.58 & & & -4.11 & & & -4.84 & \\
\hline
\end{tabular}

Table 4. The results of Johansen co-integration test

\begin{tabular}{|l|l|l|c|l|l|l|c|}
\hline \multicolumn{5}{|c|}{ Trace } & \multicolumn{4}{c|}{ Max Eigenvalue } \\
\hline $\mathrm{H}_{0}$ & $\mathrm{H}_{1}$ & Statistics & $\begin{array}{c}5 \% \\
\text { critical } \\
\text { values }\end{array}$ & $\mathrm{H}_{0}$ & $\mathrm{H}_{1}$ & Statistics & $\begin{array}{c}5 \% \\
\text { critical } \\
\text { values }\end{array}$ \\
\hline $\mathrm{r}=0$ & $r \geq 1$ & 35.26419 & 15.4947 & $\mathrm{r}=0$ & $r=1$ & 34.0322 & 14.2646 \\
\hline$r \leq 1$ & $r \geq 2$ & 1.232025 & 3.84147 & $r \leq 1$ & $\mathrm{r}=2$ & 1.23203 & 3.841466 \\
\hline
\end{tabular}

concluded that the ZA tests results corroborate the findings of the other unit root tests that all variables in the study integrated of order one (i.e., I(1)). Note that the same order of integra- tion (i.e., one, is a pre-requisite when Johansen method is used for testing for cointegration and then causality). Thus, we can proceed with the Johansen cointegration test. 
The Johansen co-integration tests results in Table 4 show that the Johansen test identifies one co-integrating vector between CAD_SA and UNEMP_SA series under the both the Trace statistics and Max Eigenvalue statistics at 5\% significance level. Therefore, CAD_SA and UNEMP_SA are co-integrated and VECM is the appropriate specification for the full-sample Granger causality tests. Table 5 shows the results of VECM ${ }^{2}$ Granger causality tests.

Based on the results of the VECM Granger causality tests in Table 5, we found that there is a unidirectional causality running from current account deficits to unemployment at the $1 \%$ significance level in the short-run, but the converse is not true. Moreover, the results of the long-run Granger causality test of the ect confirm that the ect coefficient of unemployment is negative and statistically significant at the $1 \%$ significance level and the ect coefficient of the CAD_SA is negative but insignificant.

The results of the long-run causality tests imply that current account deficits is a weakly exogenous variable, but unemployment is not; therefore, indicating the presence of unidirectional causality running from CAD_SA to UNEMP_SA in the long-run. The value of the ect coefficient of unemployment is approximately -0.000000545 and indicates the corrections to the short-run disequilibrium $(0.0000545 \%)$ will be very small per year.

As Özer (2015) concludes, the main driver of widening current account deficit is the trade imbalance resulting mostly from the heavy reliance on intermediate imports goods, mainly consist of industrially processed raw materials, which represented almost $73 \%$ of total imports in 2013. And also, since the CAD-led growth mainly resulted in substitution of domestic intermediates with imported inputs, especially in export oriented manufacturing sectors, we enter imports of intermediate goods (IMPINTG) in the VECM exogenously; and repeat the Granger causality tests together with the impulse response and variance decomposition analysis. The VECM Granger causality test results are reported in Table 6.

Granger causality tests results in Table 6 are consistent with the earlier findings suggesting that current account deficits Granger cause unemployment in Turkey with a high significance level. Based on the results of the cointegrating equation for the unemployment, we can conclude that there is a statistically significant relationship between UNEMP and IMPINTG in the long-run ${ }^{3}$, supporting our working hypothesis that CAD increases UNEMP in Turkey.

Table 5. Results of VECM Granger Causality Tests

\begin{tabular}{|c|c|c|c|}
\hline \multicolumn{2}{|l|}{ Long-run } & \multicolumn{2}{|l|}{ Short-run } \\
\hline Null hypothesis & $\begin{array}{c}\text { Test } \\
\text { statistics }\end{array}$ & Null hypothesis & $\begin{array}{c}\text { Test } \\
\text { statistics. }\end{array}$ \\
\hline $\begin{array}{l}\triangle C A D-S A \\
\text { does not Granger cause } \\
\triangle U N E M P-S A\end{array}$ & $-3.72 *$ & $\begin{array}{l}\triangle C A D-S A \\
\text { does not Granger cause } \\
\triangle U N E M P-S A\end{array}$ & $29.30 *$ \\
\hline $\begin{array}{c}\triangle U N E M P-S A \\
\text { does not Granger cause } \\
\triangle C A D \quad S A\end{array}$ & -0.03 & $\begin{array}{l}\triangle U N E M P{ }_{-} S A \\
\text { does not Granger cause } \\
\triangle C A D \quad S A\end{array}$ & 13.37 \\
\hline
\end{tabular}


The Relationship between Current Account Deficits and Unemployment in Turkey

Table 6. Results of VECM Granger Causality Tests including the imports of intermediate goods

\begin{tabular}{|c|c|c|c|}
\hline \multicolumn{2}{|l|}{ Long-run } & \multicolumn{2}{|l|}{ Short-run } \\
\hline Null hypothesis & $\begin{array}{c}\text { Test } \\
\text { statistics }\end{array}$ & Null hypothesis & $\begin{array}{c}\text { Test } \\
\text { statistics. }\end{array}$ \\
\hline $\begin{array}{l}\triangle C A D=S A \\
\text { does not Granger cause } \\
\triangle U N E M P P_{-S A}\end{array}$ & $-3.79 *$ & $\begin{array}{l}\triangle C A D-S A \\
\text { does not Granger cause } \\
\triangle U N E M P-S A\end{array}$ & $32.02 *$ \\
\hline $\begin{array}{l}\triangle U N E M P-S A \\
\text { does not Granger cause } \\
\triangle \subset A D=S A\end{array}$ & -0.37 & $\begin{array}{l}\triangle U N E M P-S A \\
\text { does not Granger cause } \\
\triangle C A D-S A\end{array}$ & 12.19 \\
\hline
\end{tabular}

This is mostly due to the mechanism that we mention in Section 2. The results are driven by intermediate technologies where the corresponding imported goods are used as inputs for the production of final goods. All these results, once again, reinforce the working hypothesis that the persistent unemployment problem in Turkey over the 2000s has strong structural features rooted in the externally fragile macroeconomic environment.

To further investigate the dynamic response between seasonally adjusted current account deficits and unemployment, particularly to get some idea about the sign of the unidirectional causality detected in previous section running from current account deficits to unemployment, we also calculate the impulse response ${ }^{4}$ of the VECM based on the generalized impulse responses, since it is not subject to orthogonality critique. Figure 6 displays the impulse responses of VECM for the variables where Granger causality was detected.

The response in unemployment due to forecast error stemming in current account deficit initially rise, goes to peak in $3^{\text {rd }}$ time horizon and then starts decline after the $8^{\text {th }}$ time horizon ${ }^{5}$. Therefore, we can say that the current account deficits increase the unemployment initially then after the $8^{\text {th }}$ time horizon it lowers the unemployment reinforcing the findings of Granger causality test. As mentioned in (Zachariadis et al., 2007), as for the existence of the cointegrating relationship between current account deficits and unemployment, we observe that shocks do not fade away and create "permanent trace" on the affected variables.

The VECM Granger approach detects the direction of causal relations within the given sample period, and does not allow us to capture the direction of causality among the variables beyond the sample period. (Bader et al., 2008) note, for instance, that to capture the Granger causality among the variables beyond sample period, one has to portion the variance of the forecast error of a certain variable into proportions attributable to shocks in each variable in the system including its own. Figure 7 displays the results of VDC.

The VDC result seems to be quite consistent with the results obtained from the VECM. The contribution of current account deficits in unemployment is $86.14 \%$, while unemployment explains less than $10.47 \%$ of an innovation in current account deficits in the $10^{\text {th }}$ time horizon. An $89.53 \%$ portion of current account deficits is explained by own innovative shocks. This shows that the VDC supports our empirical results that current account deficits Granger cause unemployment. 
Figure 6. Impulse responses to generalized one standard deviation innovations according to the VECM of seasonally adjusted the current account deficits and unemployment
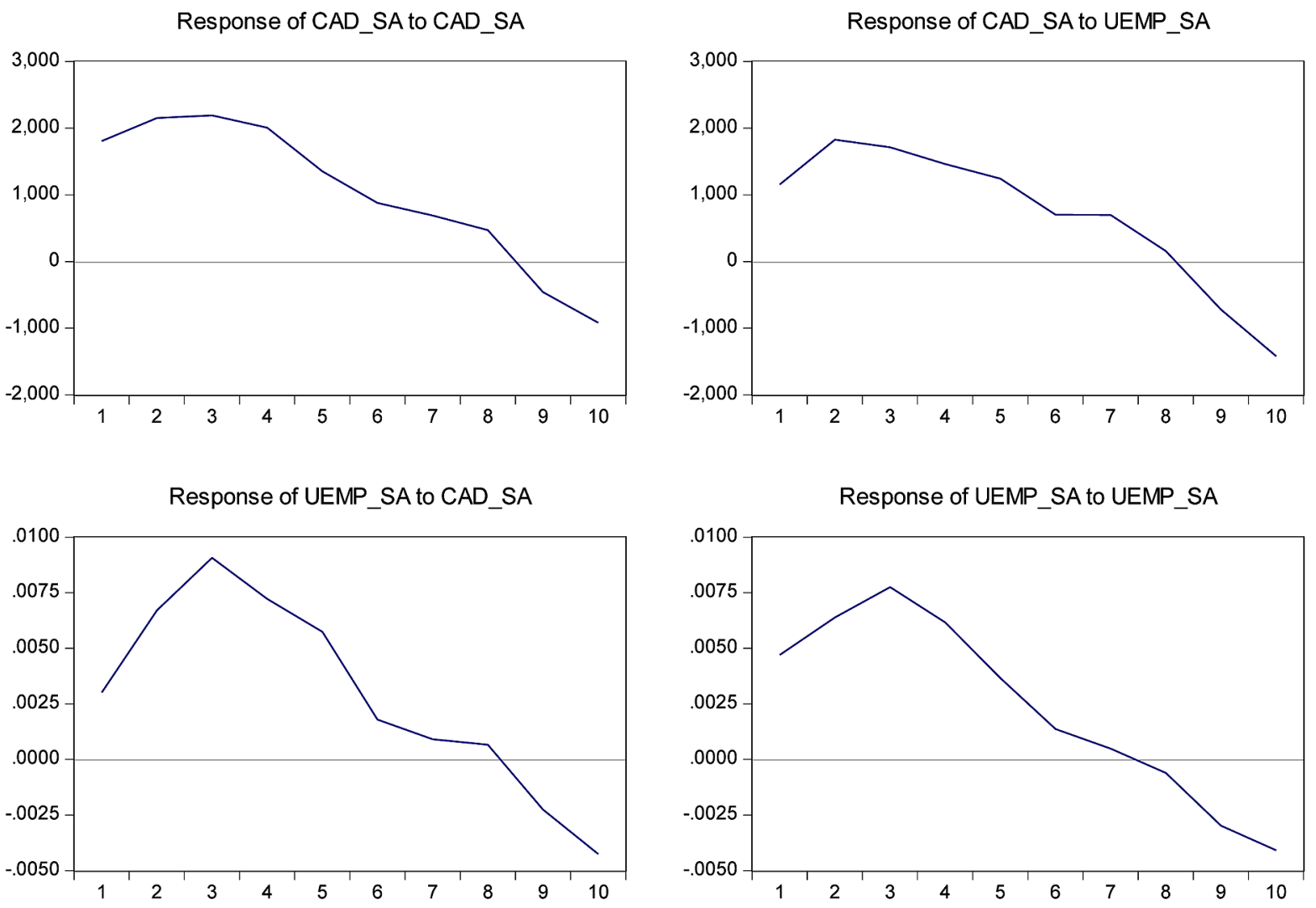

\section{CONCLUSION AND POLICY DISCUSSION}

In this chapter, using quarterly data over 2000 to 2012, we investigated the Granger-causality relationship between unemployment and current account deficits in Turkey. Our results indicated that current account deficits explain a substantial fraction of the variation in unemployment and suggest the presence of strong unidirectional causality. We interpret these findings as evidence of the structural characteristics of unemployment being embedded under the deepening external fragility of the Turkish economy over the 2000s. The persistent unemployment rates of $9-10 \%$ over a decade -despite rapid growth, suggest that the problem is by no means conjectural, and rather

structural. Based on these observations we suggest a series of policy questions for further research:

First, exchange rate appreciation stands as a key obstacle discouraging employment friendly industrialization and patterns of growth. How to avoid currency appreciation in a time of capital mobility and excessive international credit in forms of "hot" finance?

Secondly, related to this, over-emphasis on export-led growth with an over-reliance on foreign direct finance often lead to trap labor remunerations and decent job expectations to dual market structures with a minority enjoying rights of formal labor markets, at the expense of increased fragility and informality within a vast pool of unprotected/ vulnerable workers. 
Figure 7. Results of variance decomposition
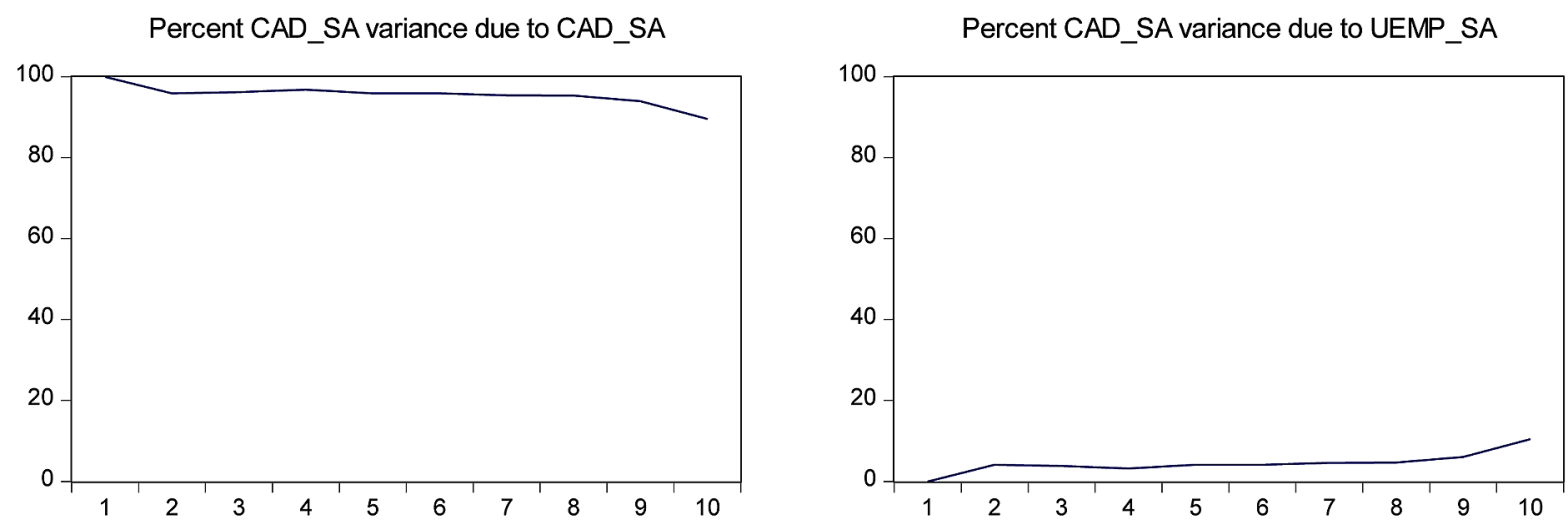

Percent UEMP_SA variance due to CAD_SA

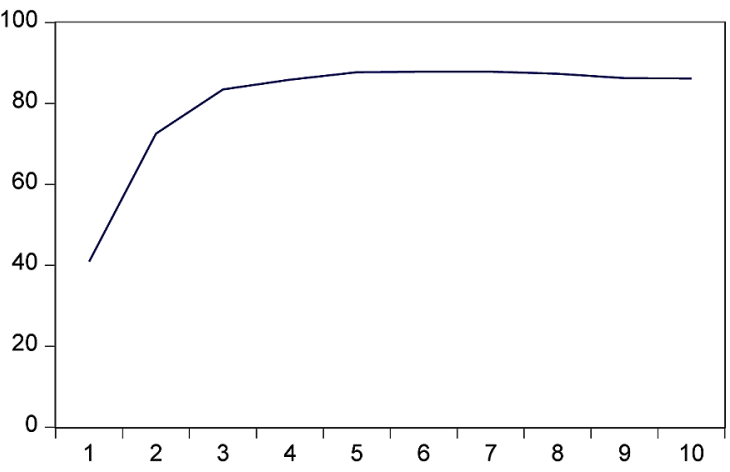

Percent UEMP_SA variance due to UEMP_SA

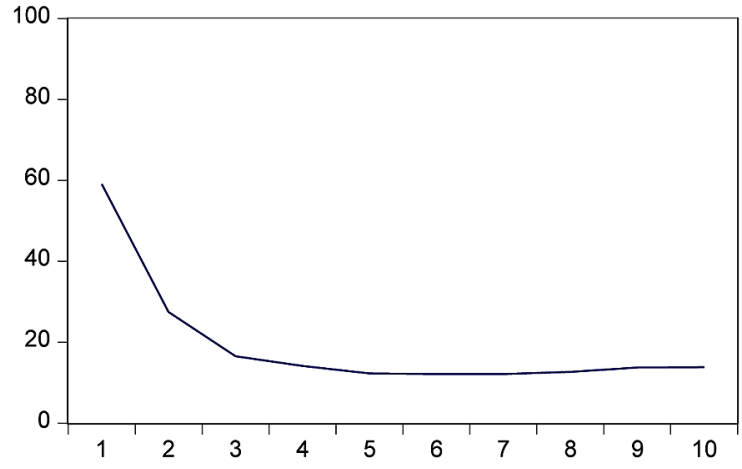

Third, in many countries the gap between wage earnings and productivity of labor is widening, with a consequent fall of the labor share out of national income. Granted that much of this mechanism has to do with the desire to lower the unit costs of labor, social protection mechanisms and efficient waging institutions ought to be found to enable workers to capture their fair share of the fruits of their labor.

Finally, we contest that the issue of inflation targeting in the context of a de-regulated, open financial account within the free floating exchange rate regimes tend to create an environment of inflation phobia with a bias against the real sectors. Ironically, employment creation has dropped off the direct agenda of most central banks just as the problems of global unemployment, infor-

malization, and poverty are taking center stage as critical world issues. The key problem is that the ongoing "financial globalization" appears primarily to redistribute shrinking investment funds and limited jobs across countries, rather than to accelerate capital accumulation across global scale (Akyüz et al, 2006; Adelman et al, 2000). Simply put, the world economy is growing too slowly to generate sufficient jobs and it is allocating a smaller proportion of its income to fixed capital formation.

It is clear that the problem of unfriendly employment patterns of speculative growth ought to be tackled first and foremost by proper macro policies at large, rather than the much fashionable proposals of micro-managerial reforms. 


\section{REFERENCES}

Abbas, F., \& Choudhury, N. (2012). Electricity consumption-economic growth Nexus: An aggregated and disaggregated causality analysis in India and Pakistan. Journal of Policy Modeling, 35(4), 538-553. doi:10.1016/j.jpolmod.2012.09.001

Abu-Bader, S., \& Abu-Qarn, A. S. (2008). Financial development economic growth: The Egyptian experience. Journal of Policy Modeling, 15(30), 887-898. doi:10.1016/j.jpolmod.2007.02.001

Agénor, P. R., Yeldan, E., Tarp-Jensen, H., \& Verghis, M. (2007). Disinflation, Fiscal Sustainability, and Labor Market Adjustment in Turkey. In P. R. Agénor, A. Izquierdo, \& H. Tarp-Jensen (Eds.), Adjustment Policies, Poverty and Unemployment: The IMMPA Framework. Basil Blackwell: Oxford University Press.

Akinlo, A. E. (2009). Electricity consumption and economic growth in Nigeria: Evidence from cointegration and co-feature analysis. Journal of Policy Modeling,33(31), 681-693. doi:10.1016/j. jpolmod.2009.03.004

Aksoy, E. (2013). Relationships between Employment and Growth from Industrial Perspective by Considering Employment Incentives: The Case of Turkey. International Journal of Economics and Financial Issues, 3(1), 74-86.

Akyüz, Y., \& Korkut, B. (2003). The Making of the Turkish Crisis. World Development, 31(9), 15491566. doi:10.1016/S0305-750X(03)00108-6

AuYong, H. H., Gan, C., \& Treepongkaruna, S. (2004). Cointegration and causality in the Asian and emerging foreign exchange markets: Evidence from the 1990s financial crises. International Review of Financial Analysis, 44(13), 479-515. doi:10.1016/j.irfa.2004.02.024

Belke, A., \& Gocke, M. (2004). Real options Effects on Employment: Does Exchange Rate Uncertainty Matter for Aggregation? IZA Working Paper, No. 1126.
Belke, A., \& Kaas, L. (2004). Exchange Rate Movements and Employment Growth: An OCA Assessment of the CEE Economies. Empirica, 31(2-3), 247-280. doi:10.1007/s10663-0040886-5

Demir, F. (2010). Exchange Rate Volatility and Employment Growth in Developing Countries: Evidence from Turkey. World Development, 38(8), 1127-1140. doi:10.1016/j.worlddev.2009.12.019

Demir, F. (2013). Growth under Exchange Rate Volatility: Does Access to Foreign or Domestic Equity Markets Matter? Journal of Development Economics, 100(1), 74-88. doi:10.1016/j. jdeveco.2012.08.001

Dergiades, T., Martinopoulos, G., \& Tsoulfidis, L. (2013). Energy consumption and economic growth: Parametric and non-parametric causality testing for the case of Greece. Energy Economics, 30(36), 686-697. doi:10.1016/j. eneco.2012.11.017

Ercan, H., \& Tansel, A. (2007). How to approach the challenge of reconciling labor flexibility with job security and social cohesion in Turkey. In Reconciling Labor Flexibility with Social Cohesion (pp. 179-205). Council of Europe.

Frenkel, R., \& Ros, J. (2010). Unemployment and the Real Exchange Rate in Latin America. World Development, 34(4), 631-646. doi:10.1016/j. worlddev.2005.09.007

Galindo, A., Izquierdo, A., \& Montero, J. M. (2007). Real Exchange Rates, Dollarization and Industrial Employment in Latin America. Emerging Markets Review, 8(4),284-298. doi:10.1016/j. ememar.2006.11.002

Grabel, I. (1995). Speculation-Led Economic Development: A Post-Keynesian Interpretation of Financial Liberalization Programmes in the Third World. International Review of Applied Economics, 9(2), 127-249. doi:10.1080/758538249 
Guilkey,D., \& Salemi, M. K. (1982). Small sample properties of three tests for Granger-Causal ordering in a bivariate stochastic system. The Review of Economics and Statistics, 64(4), 668-680. doi:10.2307/1923951

Gurgul, H., \& Lach, L. (2011). The role of Coal consumption in the economic growth of the Polish Economy in transition. Energy Policy, 4(39), 2088-2099. doi:10.1016/j.enpol.2011.01.052

Le, T. H., \& Chang, Y. (2013). Oil price shocks and trade imbalances. Energy Economics, 61(36), 78-96. doi:10.1016/j.eneco.2012.12.002

Liang, Q., \& Teng, J. Z. (2006). Financial development and economic growth: Evidence from China. China Economic Review, 3(17), 395-411. doi:10.1016/j.chieco.2005.09.003

Love, J., \& Chandra, R. (2005). Testing exportled growth in Bangladesh in a multivarate VAR framework. Journal of Asian Economics, 6(15), 1155-1168. doi:10.1016/j.asieco.2004.11.009

Meschi, E., Taymaz, E., \& Vivarelli, M. (2011). Trade, Technology and Skills: Evidence from Turkish Microdata. Labour Economics, 18(1), 60-70. doi:10.1016/j.labeco.2011.07.001

Nickell, S., \& Nicolitsas, D. (1999). How Does Financial Pressure Affect Firms? European Economic Review, 43(8), 1435-1456. doi:10.1016/ S0014-2921(98)00049-X

Nucci, F., \& Pozzolo, A. F. (2010). The Exchange Rate, Employment and Hours: What Firm-Level Data Say? Journal of International Economics, 82(2), 112-123. doi:10.1016/j.jinteco.2010.08.002

Onaran, Ö. (2008). Jobless growth in the Central and Eastern European Countries: A country specific panel data analysis for the manufacturing industry. Eastern European Economics, 46(4), 90-115. doi:10.2753/EEE0012-8775460405
Onaran, Ö. (2009). Wage Share, Globalization, and Crisis: The Case of Manufacturing Industry in Korea, Mexico, and Turkey. International Review of Applied Economics, 23(2), 113-134. doi:10.1080/02692170802700435

Onaran, Ö. (2013). Unemployment and Income Distribution in Turkey. Paper Presented at the National Industry Congress, Chamber of Engineers, December, Ankara.

Özer, M. (2015). Can Turkey be a Good Example for Balkan Nations? New Policy Reforms. In X. Richet, H. Hanic, \& Z. Grubisic (Eds.), Belgrade Banking Academy. Belgrade: Serbia.

Ribeiro, E.P., Corseuil, C. H., Santos, D., Furtado, P., Amorim, B., Servo, L., \& Souza, A. (2004). Trade Liberalization, the Exchange Rate and Job Flows in Brazil. Journal of Policy Reform, 7(4), 209-223. doi:10.1080/1384128042000285174

Ros, J., \& Skott, P. (1998). Dynamic Effects of Trade Liberalization and Currency Overvaluation under Conditions of Increasing Returns. The Manchester School of Economic and Social Studies, 66(4), 466-489. doi:10.1111/1467-9957.00118

Shahbaz, M. (2012). Does trade opennes affect lung run growth? Cointegration, causality and forecast error variance decomposition tests for Pakistan. Economic Modelling, 38(29), 23252339. doi:10.1016/j.econmod.2012.07.015

Taymaz, E., \& Voyvoda. (2009). Labor Employment and Productivity Growth in Turkish Manufacturing. METU.

Taymaz, E., \& Özler, Ş. (2005). Labor Market Policies and EU Accession: Problems and Prospects for Turkey. METU ERC Working Papers in Economics no 04/05.

Taymaz, E., Voyvoda, E., \& Y1lmaz, K. (2008). Türkiye Imalat sanayinde Yapısal Dönüşüm, Üretkenlikve Teknolojik Değişme Dinamikleri. METU ERC Working Papers in Economics, No 08/04. 
Telli, Ç., Voyvoda, E., \& Yeldan,E. (2006). Modeling General Equilibrium for Socially Responsible Macroeconomics: Seeking For the Alternatives to Fight Jobless Growth in Turkey. METU Studies in Development, 33(2), 255-293.

Tunalı, İ. (2003). Background Study on the Labour Market and Employment in Turkey. Report prepared for the European Training Foundation.

TURKSTAT. (n.d.). Household Labour Surveys. Author.

UNCTAD. (2006). Trade and Development Report. Geneva: United Nations.

Yeldan, E. (2006). Neo-Liberal Global Remedies: From Speculative-led Growth to IMF-led Crisis in Turkey.The Review of Radical Political Economics, 38(2), 193-213. doi:10.1177/0486613405285423

Yeldan, E. (2011). Macroeconomics of Growth and Employment: The Case Turkey. Employment Working Paper No 108. Geneva: ILO.

Yeldan, E. (2012). Growth and Employment in Turkey. Paper presented at the Workshop on The national consultation process on UN's post-2015 development agenda.' International Labour Organization, Turkey Office.

Yeldan, E., \& Kolsuz, G. (2014). 1980-Sonras1 Türkiye Ekonomisinde Büyümenin Kaynaklarının Ayrıştırılması. Çalışma ve Toplum, 40(1), 49-66.

Zachariadis, T., \& Pashourtidou, N. (2007). An empirical analysis of electricity consumption in Cyprus. Energy Economics, 53(29), 183-198. doi:10.1016/j.eneco.2006.05.002

\section{ENDNOTES}

1 See Kara et al. (2013) and Akçay et al. (2008) for a comprehensive investigation of the nature and causes of the current account imbalances in Turkey. Bénassy-Quéré et al. (2008) and Medina et al. (2010) report on the current account positions and consequences for the emerging market economies at large.

2 We also evaluated the robustness of the VECM by using normality residual test of Jarque-Bera, the autocorrelation LM test, and White heteroskedasticity test with no cross terms. The autocorrelation LM test indicates that we fail to reject the null hypothesis of serial correlation up to $12 \mathrm{lag}$. The joint test for the residual vector leads to non-rejection of null hypothesis that it follows a normal multivariate distribution, since computed value of the Jarque-Bera test statistics is 2.63 with 0.6212 probability value. Also, White heteroskedasticity test with no cross terms indicates the absence of heteroskedasticity in errors. Since the VECM passes all tests the successfully, we can conclude that the residuals are Gaussian white noise.

3 The estimated value of the coefficient of IMPINTG is $-2.96 \mathrm{E}-07$ with a $\mathrm{t}$-value of -2.39565 .

4 Inclusion of the IMPINTG as an exogenous variable in VECM doesn't change the results of IRFs and VDCs. Both results are quite consistent with the results of Granger causality tests.

5 Impulse response of UNEMP_SA to CAD_SA is significant. 